\title{
A renin-angiotenzin-aldoszteron rendszert gátló gyógyszerek alkalmazása szívinfarktust túlélt betegekben. Hazai és nemzetközi regiszteradatok
}

\author{
Jánosi András \\ Gottsegen György Országos Kardiológiai Intézet, Nemzeti Infarktus Regiszter, Budapest \\ Levelezési cím: \\ Prof. dr. Jánosi András, c. egyetemi tanár, Gottsegen György Országos Kardiológiai Intézet, Nemzeti Szívinfarktus Regiszter, \\ 1450 Budapest, Haller u. 29., e-mail: andras.janosi@kardio.hu
}

\begin{abstract}
A szerző a Nemzeti Szívinfarktus Regiszter adataira hivatkozva megállapítja, hogy a szívinfarktus miatt kezelt betegek akut ellátásának rendszere jelentősen javította a szívinfarktusos betegek korai prognózisát, de a szekunder prevenció hiányosságai miatt a betegek 1 éves halálozásának aránya kedvezőtlen. Jelenleg a szekunder prevenció fogalmába tartozó tevékenységek/beavatkozások közül csak a túlélést igazoltan kedvezően befolyásoló gyógyszeres kezelésre vonatkozóan vannak adatok. A szerző jelen összeállításban 32057 infarktus miatt kezelt beteg kórházi elbocsájtásakor javasolt gyógyszerek közül a renin-angiotenzin-aldoszteron rendszert (RAAS) -gátló gyógyszeres kezelés gyakoriságát vizsgálja és hasonlítja nemzetközi adatokhoz. Magyarországon a kórházi távozáskor a betegek 84,4\%-a RAAS-gátló-kezelésben részesült és ezen betegcsoport 93,3\%-a angiotenzinkonvertálóenzim-gátló típusú gyógyszert kapott. Nemzetközi összehasonlításban ez az arány hasonló a SWEDEHEART Regiszter által közölt értékhez (84,6\%). A RAAS-gátló-kezelés mindkét típusú infarktus esetén, Magyarországon és Svédországban nagyobb arányban kerül alkalmazásra, mint Észtországban (78\%), illetve Norvégiában (61\%). A magyar és a svéd gyakorlat megfelel a nemzetközi ajánlásnak.
\end{abstract}

Kulcsszavak: szívinfarktus, szekunder prevenció, renin-angiotenzin-aldoszteron rendszer müködését gátló gyógyszerek, infarktusregiszter

Use of drugs that inhibit the renin-angiotensin-aldosterone system in patients who have survived myocardial infarction - domestic and international registry data

Referring to data from the National Myocardial Infarction Registry, the author finds that the system of acute care for patients treated for myocardial infarction significantly improved the early prognosis of patients with myocardial infarction. Still, the 1-year mortality rate is unfavourable due to deficiencies in secondary prevention. Currently, of the activities/interventions included in the concept of secondary prevention, only data are available for pharmacotherapy that has been shown to have a positive effect on survival. In the present compilation, the author examines the frequency of medication that inhibits the renin-angiotensin-aldosterone system (RAAS) among the drugs recommended for hospital discharge of 32,057 patients treated for infarction and compares it with international data. In Hungary, $84.4 \%$ of patients received RAAS inhibitor treatment on hospital discharge, and $93.3 \%$ of this patient group received angiotensinconverting enzyme inhibitor-type medication. In international comparison, this ratio is similar to the value reported by the SWEDEHEART Register (84.6\%). RAAS inhibitor treatment for both types of infarction is used in Hungary and Sweden at a higher rate than in Estonia (78\%) and Norway (61\%). The Hungarian and Swedish practice complies with the international recommendation.

Keywords: myocardial infarction, secondary prevention, drugs that inhibit the renin-angiotensin-aldosterone system, myocardial infarction register

A kézirat 2020. 10. 05-én érkezett a szerkesztőségbe, 2020. 12. 01-jén került elfogadásra. 
A szívinfarktust túlélt betegek életkilátásai az elmúlt években lényegesen javultak ebben az akut ellátás során alkalmazott perkután koronáriaintervenció és a másodlagos megelőzés szempontjából fontos gyógyszerek használata egyaránt igazolható jelentőséggel bírnak (1). A Nemzeti Szívinfarktus Regiszter (NSZR) adatainak nemzetközi összehasonlítása egyértelmüen igazolja, hogy a betegek akut ellátása, a betegek rövid távú prognózisa megfelel a más országokban megfigyelt eredményeknek (2), a hosszú távú prognózis azonban a várhatónál rosszabb. A magas, 1 éves halálozás több tényező együttes következménye:

- alacsony a rehabilitációban részesültek aránya,

- nincs érvényes gondozási protokoll,

- ismeretlen, hogy milyen a dohányzást elhagyók és a rendszeres fizikai aktivitással élők aránya.

A jelenleg rendelkezésre álló egészségügyi adatok csak a szekunder prevenció szempontjából szóba jövő gyógyszeres kezelés kérdésének vizsgálatát teszik lehetővé. Előző tanulmányunkban (3) igazoltuk, hogy a kórházi elbocsájtáskor a betegek optimális aránya kap megfelelő gyógyszeres kezelés folytatására javaslatot, de 1 évvel az indexinfarktus után az adherensek aránya nem éri el a 60\%-ot (3). Jelen feldolgozásunkban azt kívántuk elemezni, hogy a távozáskor javasolt RAAS-gátlókon belül milyen volt a ACEI és az ARB hatásmechanizmusú gyógyszerek aránya, különösen annak ismeretében, hogy az érvényes ajánlás az ARB-kezelést, akkor javasolja, ha a beteg valamilyen okból nem tolerálja az ACEI-terápiát (3).

\section{Módszer}

Az NSZR az egyetlen hazai kardiológiai adatbázis, amely egy betegséggel kapcsolatos minden fontos ellátási adatot tartalmaz a prehospitális ellátástól az indexeseményt követő 1 évvel bezárólag. A vizsgálat módszerét több korábbi közleményben ismertettük (5). $A z$ adatbázis teljességét a finanszírozott kezelésekkel összehasonlítva vizsgáljuk. Az elmúlt években a regisztrált események aránya folyamatosan meghaladta a 90\%-ot, 2019-ben 92\% volt. A kórházi kezelésre vonatkozó adatlapon - RAAS-gátló kezelés esetén - az alábbi terápiás lehetőségek kerülhettek jelölésre:

- ACEI,

- ACEI + hidroklorotiazid,

- ACEl + indapamid,

ARB,

- $\mathrm{ARB}+$ indapamid,
- $\mathrm{ARB}+$ hidroklorotiazid

Jelen feldolgozásunkban az ACEI, illetve ACEI + diuretikum kezeléseket az ACEl-kezelési csoportba soroltuk, hasonlóan jártunk el az ARB-kezelés esetén is. Jelen feldolgozásunkban nem kívántuk vizsgálni a kórházi elbocsájtáskor javasolt RAAS-gátló-kezelés és az 1 éves túlélés kapcsolatát. Egy jelenleg közlés alatt lévő publikációban - számos egyéb adat mellett - összehasonlítottuk a hazai RAAS-gátló-kezelés gyakoriságát, több olyan ország (Svédország, Norvégia, Észtország) adatával, ahol infarktusregiszter müködik. Ezen összehasonlításnál a 2014.01.01-2017.12.31 közötti adatokat dolgoztuk fel, és a RAAS-gátló-kezelés (ACEl vs. ARB) módját vizsgáltuk.

\section{Eredimények}

\section{A regisztrált betegek száma és diagnózis szerinti megoszlása}

2018. 01. 01. és 2020. 04. 30 között 35092 beteget regisztráltunk heveny miokardiális infarktus (AMI) diagnózissal. A betegek 42,2\%-ánál (14 811 beteg) ST-elevációval járó miokardiális infarktus (STEMI), míg 20281 esetben (57,8\%) nem ST-elevációval járó infarktus (NSTEMI) volt a kezelés indoka. A kórházban 3035 beteg halt meg, a kórházi halálozás a STEMI-betegeknél 10,1\%, az NSTEMI-betegcsoportban 7,6\% volt. A kórházi elbocsájtáskor javasolt RAAS-gátló-kezelés vizsgálatakor 32057 beteg adatait dolgoztuk fel.

\section{A RAAS-gátló-kezelés módja és az infarktus típusa}

A vizsgált időszakban a betegek 84,4\%-a (27 051 beteg) kapott RAAS-gátló-kezelést, de a kezelés részleteinek (ACEI vs. ARB) megjelölése 2649 esetben hiányzott. A RAAS-gátló-kezelés részleteiről 24402 betegnél rendelkezünk adatokkal. Az AMI-diagnózissal regisztrált 24402 beteg 93,3\%-a ACEl-kezelésben részesült, míg 1646 betegnél ARB-kezelést javasoltak a távozáskor. Az 1. táblázatban a kezelés módját az infarktus típusa szerint vizsgálva tüntettük fel. NSTEMI-ben az ARB-kezelést lényegesen gyakoribbnak találtuk $(6,4 \%)$ mint STEMI esetén $(3,4 \%)$. A kezelés gyakoriságát regionális bontásban is megvizsgáltuk. STEMI esetén Közép- és Kelet-Magyarországon nagyon hasonló arányban kaptak a betegek RAAS-gátló-kezelést (87\%, illetve $86,1 \%)$, míg Nyugat-Magyarországon ez az arány $77,9 \%$ volt. NSTEMI-ben hasonló tendenciát figyeltünk meg: a kezelési arány $79,6 \%-89,1 \%-87,1 \%$

TÁBLÁZAT. A kórházi elbocsájtáskor javasolt RAAS-gátló-kezelés (\%) (Nemzeti Infarktus Regiszter 2014. 01. 01-2020. 04. 30.)

\begin{tabular}{|l|c|c|c|c|c|}
\hline & ACEI & ARB & ACEI/ARB & $\begin{array}{c}\text { Nem kapott ilyen } \\
\text { kezelést }\end{array}$ & Összesen \\
\hline STEMI & $9498(71,4)$ & $447(3,4)$ & $1134(8,5)$ & $2231(16,7)$ & $13310(100)$ \\
\hline NSTEMI & $13258(70,7)$ & $1199(6,4)$ & $1515(8)$ & $2775(14,9)$ & $18747(100)$ \\
\hline
\end{tabular}

ACEI/ARB = a kezelés módja nincs részletezve 
2. TÁBLÁZAT. A RAAS-gátló-kezelés gyakoriságának nemzetközi összehasonlítása azon országokban, ahol folyamatosan működő Infarktus regiszter működik (2014-2017)

\begin{tabular}{|c|c|c|c|c|}
\hline & $\begin{array}{l}\text { Magyar- } \\
\text { ország }\end{array}$ & $\begin{array}{l}\text { Svéd- } \\
\text { ország }\end{array}$ & $\begin{array}{l}\text { Nor- } \\
\text { végia }\end{array}$ & $\begin{array}{l}\text { Észt- } \\
\text { ország }\end{array}$ \\
\hline \multicolumn{5}{|l|}{ STEMI } \\
\hline $\begin{array}{l}\text { RAAS-gátlás igen } \\
(\%)\end{array}$ & 83,9 & 84,6 & 61,5 & 78 \\
\hline \multicolumn{5}{|l|}{ NSTEMI } \\
\hline $\begin{array}{l}\text { RAAS-gátlás igen } \\
(\%)\end{array}$ & 86,4 & 76,3 & 49,8 & 76,5 \\
\hline
\end{tabular}

volt a nyugati, a közép és a keleti régióban. Mindkét típusú infarktus esetén a $\mathrm{PCl}$-kezelésben részesült betegek nagyobb arányban kaptak RAAS-gátló gyógyszert: STEMI esetén $85,4 \%$ vs. $68,3 \%$, míg NSTEMI-ben $87,6 \%$ vs. $77,5 \%$.

\section{Az infarktus miatt kezelt betegek RAAS-gátló kezelésének nemzetközi összehasonlítása}

A RAAS-gátló-kezelés gyakoriságát az egyes országokban a 2. táblázatban foglaltuk össze. STEMI-ben a kórházi elbocsájtáskor javasolt RAAS-gátló hatású gyógyszerjavaslat Magyarországon és Svédországban igen hasonló (83,9\% vs. 84,6\%), Észtországban 78\%, míg Norvégiában kevesebb, mint a betegek kétharmada $(61,5 \%)$ kapott ilyen irányú kezelési javaslatot. NSTEMI-ben Magyarországon találtuk a leggyakoribbnak a RAAS-gátló gyógyszerek kezelési javaslatát, Svédországban és Észtországban 10\%-kal alacsonyabb $(76,3 \%$, illetve $76,5 \%)$ volt, míg Norvégiában nem érte el az 50\%-ot.

\section{Megbeszélés}

A RAAS-gátló gyógyszerek széles körü alkalmazása a keringési rendszer betegségeinek gyógyításában évtizedek óta jól ismert. Az angiotenzinkonvertálóenzim-gátló szerek blokkolják az angiotenzin I-angiotenzin II átalakulást és a folyamat „mellékterméke” a bradikininfelszaporodás, ami több angiotenzinrecep-

\begin{tabular}{|c|c|c|}
\hline & ACEI & ARB \\
\hline Csökkenti az endotheldiszfunkciót & + & + \\
\hline Csökkenti a gyulladást & + & - \\
\hline Csökkenti a sejtek adhézióját & + & + \\
\hline Antitrombotikus hatásuk van & + & \pm \\
\hline Antiateroszklerotikus hatásúak & + & + \\
\hline Csökkenti a sejtek apoptózisát & + & - \\
\hline Fibrinolitikus aktivitással rendelkezik & + & \pm \\
\hline
\end{tabular}

tor müködését befolyásolja, valamint fokozza a szöveti plazminogénaktivátor-szintézist. A folyamat végeredménye az érendothel megnövekedett plazminogénaktivátor-inhibitor-1 szekréciója, ami más vazoaktív anyagokkal együtt csökkenti az akut koszorúér-események kialakulását (6). A receptorblokkolók az angiotenzinreceptorokhoz kötődve blokkolják az angiotenzin hatását és - hasonlóan ACEI-hatású szerekhez több ponton kedvező érrendszeri hatásuk van. ARB-hatású szerek szemben az ACEl-kel nem csökkentik az akut koszorúér-események gyakoriságát. Az ACEI- és az ARB-hatású gyógyszerek hatásmechanizmusának összehasonlításának részleteit a 3 . táblázat tartalmazza (6). Az ACEl-k közül az endothelre kifejtett kedvező hatás különösen azon készítmények (perindopril, ramipril) esetén jelentős, amelyek szöveti affinitása magas (7, 8). A kétféle hatásmechanizmusú gyógyszercsoport hatásának összehasonlítása évek óta az érdeklődés homlokterében van. Strauss (9) „ARB-MI paradox”-ról ír, mivel metaanalízisük során azt találták, hogy az ARB-kezelésben részesült betegeknél gyakoribb volt a szívinfarktus. Ezt a megfigyelést nem erősítette meg az ALLHAT-vizsgálat (10) vagy más metaanalízis. Az ajánlásokban általában az ACEI az elsőként alkalmazandó szer, intolerancia vagy mellékhatás esetén az ARB-kezelés ajánlott (4). A legtöbb hipertóniakezelési ajánlásban mindkét szer elsővonalbeli kezelésként is alkalmazható. A svéd infarktusregiszter adatai szerint a RAAS-gátló-kezelést kapó betegek 3 éves halálozása közel 10\%-kal alacsonyabb volt, mint azon betegeké, akik ilyen kezelésben nem részesültek (11). Az ACEI-, illetve ARB-kezelést kapó betegek túlélésében nem találtak különbséget, szemben azon tanulmánnyal, amelyben az ACEl-kezelés posztinfarktusos betegeknél jobb 5 éves túlélést biztosított, mint az ARB-terápia (12). A svéd vizsgálat külön érdekessége, hogy az ACEl/ARB-kezelés kedvező volt, csökkent, illetve rossz vesefunkció esetén is, beleértve azon posztinfarktusos betegeket, akik dialízis-kezelést kaptak. Saját eredményeink az ACEl-kezelés dominanciáját igazolják: mindkét típusú infarktus esetén a betegek 71\%-a ACEl-kezelést, illetve kezelési javaslatot kaptak. Kiemelendő, hogy a magyar terápiás gyakorlat megfelel a nemzetközi ajánlásnak, lényegesen jobb, mint a norvég vagy az észt gyakorlat:10 infarktust túlélt beteg közül 8 - az akut szakban - RAAS-gátló-kezelésben részesült, 7 beteg pedig ACEI-t kapott.

\section{Ko̊vetkeztetés}

Magyarországon az infarktusos betegek RAAS-gátló-kezelése jól követi az érvényes ajánlást, nemzetközi összehasonlításban is kiemelkedően magas az ilyen kezelést kapó betegek aránya. Az adherencia arányának javítása a késői életkilátások javulását eredményezhetné. 


\section{Lehetséges érdekbeli ütközések számbavétele}

A közzétett dolgozat megjelenését az Egis Gyógyszer Zrt. támogatta. A dolgozat megállapításai új ismereteket tartalmaznak. Az ajánlással és a szereplő gyógyszerekkel kapcsolatosan a szerzőnek pénzügyi érdekeltsége nincs.

\section{Irodalom}

1. Jernberg T, Johanson P, Held C, et al. Association between adoption of evidence-based treatment and survival for patients with STelevation myocardial infarction. JAMA 2011; 305: 1677-1684. https://doi.org/10.1001/jama.2011.522

2. Bloendal M, Ainia T, Andreka P, Edfords R, Halvorsen S, Jernberg $\mathrm{T}$, Jortveit J, Marandi T, Janosi A. Comparison of management and outcomes of ST-segment elevation myocardial infarction patients in Estonia, Hungary, Norway and Sweden according to national ongoing registries. Abstract, ESC Congress 2020.08.29-09.01; Amsterdam: European Society of Cardiology; 2020.

3. Jánosi $A$, Ofner $P$, Kiss $Z$, et al. Adherence to medication after myocardial infarction and its impact on outcome: a registry-based analysis from the Hungarian Myocardial Infarction Registry. [Szívinfarktust túlélt betegek terápiahűsége a másodlagos megelőzés szempontjából fontos gyógyszeres kezelésekhez.] Orv Hetil 2017; 158: 1051-1057. [Hungarian] https://doi.org/10.1556/650.2017.30795 4. Ibanez B, James S, Agewall S, et al. 2017 ESC Guidelines for the management of acute myocardial infarction in patients presenting with ST-segment elevation: The Task Force for the management of acute myocardial infarction in patients presenting with ST-segment elevation of the European Society of Cardiology (ESC). Eur Heart $J$
2018; 39: 119-177. https://doi.org/10.1093/eurheartj/ehx393

5. Jánosi A. A szívinfarktus miatt kezelt betegek ellátásának és prognózisának fontosabb adatai - Nemzeti Szívinfarktus Regiszter 2015. Cardiologia Hungarica 2016; 46: 70-75

6. Dezsi CA, Szentes V. Effects of angiotensin-converting enzyme inhibitors and angiotensin receptor blockers on prothrombotic processes and myocardial infarction risk. Am J Cardiovasc Drugs 2016; 16: 399-406. https://doi.org/10.1007/s40256-016-0185-0

7. Comini L, Bachetti T, Cargnoni A, et al. Therapeutic modulation of the nitric oxide: all ace inhibitors are not equivalent. Pharmacol Res 2007; 56: 42-48. https://doi.org/10.1016/j.phrs.2007.03.004

8. Ruschitzka F, Taddei S: Angiotensin-converting enzyme inhibitors: first-line agents in cardiovascular protection? Eur Heart J 2012; 33: 1996-1998. https://doi.org/10.1093/eurheartj/ehs108

9. Strauss MH, Hall AS. Angiotensin receptor blockers may increase risk of myocardial infarction: unraveling the ARB-MI paradox. Circulation 2006; 114: 838-854.

https://doi.org/10.1161/CIRCULATIONAHA.105.594986

10. ALLHAT Officers, Coordinators for the ALLHAT Collaborative Research Group: Major outcomes in high-risk hypertensive patients randomized to angiotensin-converting enzyme inhibitor or calcium channel blocker vs diuretic: The Antihypertensive and Lipid-Lowering Treatment to Prevent Heart Attack Trial (ALLHAT). JAMA 2002; 288: 2981-2997. https://doi.org/10.1001/jama.288.23.2981

11. Evans M, Carrero JJ, Szummer K, et al. Angiotensin-converting enzyme inhibitors and angiotensin receptor blockers in myocardia infarction patients with renal dysfunction. J Am Coll Cardiol. 2016; 67: 1687-1697. https://doi.org/10.1016/j.jacc.2016.01.050

12. Hara M, Sakata Y, Nakatani D, et al. Comparison of 5-year survival after acute myocardial infarction using angiotensin-converting enzyme inhibitor versus angiotensin II receptor blocker. Am J Cardiol 2014; 114: 1-8. https://doi.org/10.1016/j.amjcard.2014.03.055
HIPERTÓNIA

ÉS KARDIOVASZKULÁRIS PREVENCIÓ
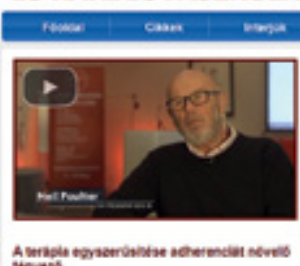

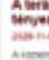

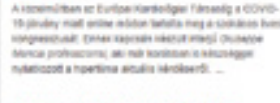

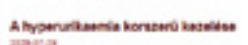

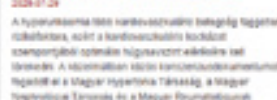

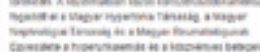

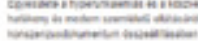

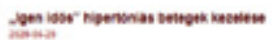

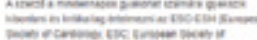

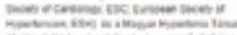

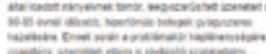

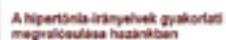
mascos wom
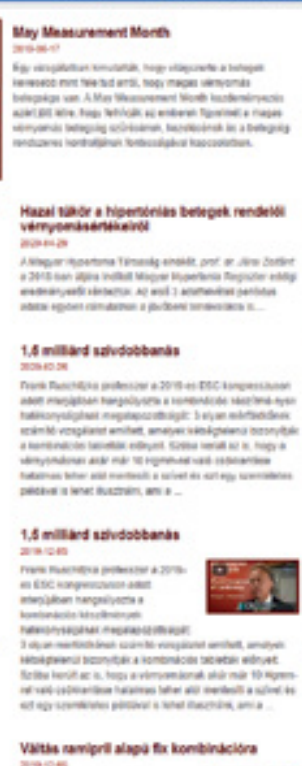

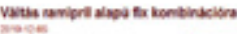

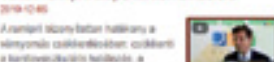

Látogasson el weboldalunkra,

ahol sok szakmai aktualitás mellett további kardiológiai témájú szakmai

anyagokat talál:

- összefoglaló közlemények, szakcikkek,

- hazai és kongresszusi beszámolók,

- videointerjúk belföldi és

• külföldi szaktekintélyekkel,

- videotudósítások belföldi és

• külföldi kongresszusokról,

- szakmai hírek, aktuális események

www.hipertonia.olo.hu 